* Roy Sadovsky, D.V.M.

IA 97-024.

* Derek Stephens

IA 97-008.

* Larry D. Wicks

IA 94-024.

Lonnie Randa 11 Wilson

IA 97-050.

* Marc W. Zuverink

IA 95-022.

\title{
NOTICES OF VIOLATION
}

John T. Altman

IA 97-085.

Steven D. DeNise

IA 97-077

Kent Dvorak

IA 97-079.

Jose R. Garza

IA 97-038.

Jeffrey $W$. Holybee

IA 97-072

Stephen M. Jozwiak

IA 97-086.

Michael Redl in

IA 97-088.

Kelly N. Ross

IA 97-075.

Randa11 L. Rumley

IA 97-071. 
Bruce Sensenbach

IA 97-069...

Marvin N. Shook

IA 97-073.

. B-35

Donald Smith

IA 97-056.

Lanny R. Tillman

IA 97-089.

B- 43 


\section{ENFORCEMENT ACTIONS: SIGNIFICANT ACTIONS RESOLVED}

INDIVIDUAL ACTIONS

$$
\text { July - December } 1997
$$

\section{INTRODUCTION}

This issue and Part of NUREG-0940 is being published to inform a11 Nuclear Regulatory Commission (NRC) licensees about significant enforcement actions taken against individuals for the second half of 1997 . Enforcement actions are issued in accordance with the NRC's Enforcement Policy, published as NUREG-1600, "General Statement of Policy and Procedure for NRC Enforcement Actions."

In promulgating the regulations concerning deliberate misconduct by unlicensed persons (55 FR 40664. August 15, 1991), the Commission directed that a 1ist of a11 persons who are currently the subject of an order restricting their employment in licensed activities be made available with copies of the 0rders. These enforcement actions will be included for each person as long as the actions remain effective. The Commission believes this information may be useful to licensees in making employment decisions.

The NRC pubiishes significant enforcement actions involving reactor and materials 7icensees as Parts II and III of NUREG-0940, respectively. 
in NRC-licensed activities, as defined in Paragraph IV.1 above. In the notification, he will include a statement of his commitment to comply with regulatory requirements and address why the NRC should have confidence that he will comply with regulatory requirements, and the name, address and telephone number of his employer or entity where he will be involved in licensed activities.

The Director, Office of Enforcement, may relax or rescind, in writing, any of the above conditions upon a showing by Mr. Bandy of good cause.

\section{V}

In accordance with 10 CFR 2.202, Mr. Bandy must, and any other person adversely affected by this Order may, submit an answer to this Order, and may request a hearing within 20 days of its issuance. Where good cause is shown, consideration will be given to extending the time to request a hearing. A request for extension of time must be made in writing to the Director, Office of Enforcement, U.S. Nuclear Regulatory Commission, Washington, D.C. 20555, and include a statement of good cause for the extension. The answer may consent to this Order. Unless the answer consents to this Order, the answer shall, in writing and under oath or affirmation, specifically admit or deny each allegation or charge made in this Order and shall set forth the matters of fact and law on which Mr. Bandy, or any other such person adversely affected, relies and 
the reasons as to why the Order should not have been issued. Any answer or request for a hearing shall be submitted to the Secretary, U.S. Nuclear Regulatory Commission, ATTN: Chief, Docketing and Service Section, Washington, D.C. 20555. Copies also shall be sent to the Director, Office of Enforcement, U.S. Nuclear Regulatory Commission, Washington, D.C. 20555, to the Assistant General Counsel for Hearings and Enforcement at the same address, to the Regional Administrator, NRC Region IV, 611 Ryan Plaza Drive, Suite 400, Arlington, Texas 76011, and to Mr. Bandy. If a person other than Mr. Bandy requests a hearing, that person shall set forth with particularity the manner in which his or her interest is adversely affected by this Order and shall address the criteria set forth in 10 CFR 2.714(d).

If a hearing is requested by Mr. Bandy or a person whose interest is adversely affected, the Commission will issue an Order designating the time and place of any hearing. If a hearing is held, the issue to be considered at such hearing shall be whether this Order should be sustained.

Pursuant to 10 CFR 2.202(c)(2)(i), Mr. Bandy may, in addition to demanding a hearing, at the time the answer is filed or sooner, move the presiding officer to set aside the immediate effectiveness of the Order, on the ground that the Order, including the need for immediate effectiveness, is not based on adequate evidence but on mere suspicion, unfounded allegations, or error. 
In the absence of any request for a hearing, or written approval of an extension of time in which to request a hearing, the provisions specified in Section IV above shall be final 20 days from the date of this Order without further order or proceedings. If an extension of time for requesting a hearing has been approved, the provisions specified in Section IV shall be final when the extension expires if a hearing request has not been received. AN ANSWER OR A REQUEST FOR HEARING SHALL NOT STAY THE IMMEDIATE EFFECTIVENESS OF THIS ORDER.

FOR THE NUCLEAR REGULATORY COMMISSION

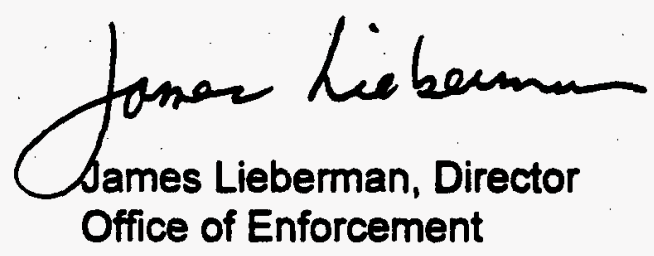

Dated at Rockville, Maryland this / Trhday of November 1997 


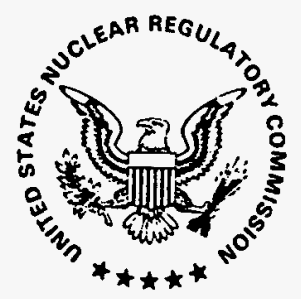

\author{
UNITED STATES \\ NUCLEAR REGULATORY COMMISSION \\ WASHINGTON, D.C. 20555-0001 \\ June 23, 1997
}

IA 97-049

Mr. Jeffrey Lee Barnhart

[HOME ADDRESS DELETED

UNDER 2.790]

SUBJECT: $\quad$ ORDER PROHIBITING INVOLVEMENT IN NRC-LICENSED ACTIVITIES

(EFFECTIVE IMMEDIATELY) (OI REPORT NO. 3-97-005)

The enclosed Order Prohibiting Involvement in NRC-Licensed Activities is being issued as a consequence of your deliberate falsification of information which you provided on an application in order to obtain access authorization at Northern States Power Company's (1icensee) Prairie Island Nuclear Generating Plant. The Order prohibits your involvement in NRC-1icensed activities for a period of five years.

The NRC determined that on December 7, 1995, you deliberately falsified information on your security questionnaire in order to obtain unescorted access to Prairie Island Nuclear Generating Plant. On this questionnaire, you assumed the identity of your deceased brother and provided false statements regarding your history of drug use and past conviction for possession of illegal drugs. The false information that you submitted on your questionnaire caused you to be in violation of 10 CFR 50.5, "Deliberate Misconduct."

Specifically, 10 CFR 50.5(a)(2) provides, in part, that any employee of a contractor may not deliberately submit to a licensee or a licensee's contractor information that the person submitting the information knows to be incomplete or inaccurate in some respect material to the NRC. The false information that you submitted was material because 1 icensees are required to consider background information in making a determination as to whether to grant you unescorted access in accordance with 10 CFR 73.56. The background investigation must, at a minimum, verify an individual's true identity, verify an individual's character and reputation, and develop information concerning an individual's criminal history. The failure of an individual to provide this information is sufficient cause for denying him or her unescorted access to a nuclear power plant.

Pursuant to Section 223 of the Atomic Energy Act of 1954, as amended, 42 U.S.C. 2273, any person who willfully violates, attempts to violate, or conspires to violate any provision of this Order shall be subject to criminal prosecution as set forth in that section. Violation of this Order may also subject the person to a civil monetary penalty.

Questions concerning the Order may be addressed to James Lieberman, Director, Office of Enforcement. Mr. Lieberman can be reached at telephone number (301) 415-2741. 
In accordance with 10 CFR 2.790 of the NRC's "Rules of Practice," a copy of this letter and the enclosure with your home address removed will be placed in the NRC's Public Document Room.

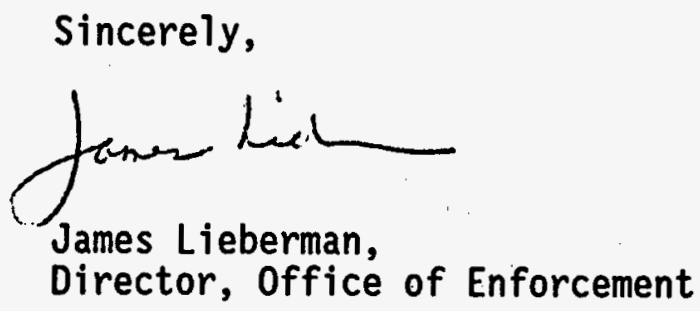

Enclosure: Order Prohibiting Involvement in

NRC-Licensed Activities (Effective Immediately)

cc w/enc] [WITH HOME ADDRESS DELETED UNDER 2.790]:

Mr. M. D. Wadley

Vice President, Nuclear Generation

Northern States Power Company

Plant Manager, Prairie Island

John W. Ferman, Ph.D.

Nuclear Engineer, MPCA

State Liaison Officer, State

of Minnesota

State Liaison Officer, State of Wisconsin

Tribal Council, Prairie Island

Dakota Community 
In the Matter of

MR. JEFFREY LEE BARNHART

A.k.a. GREGORY KENNETH BARNHART

IA $97-049$

ORDER PROHIBITING INVOLVEMENT IN

NRC-LICENSED ACTIVITIES

(EFFECTIVE IMMEDIATELY)

\section{I}

Mr. Jeffrey Lee Barnhart was a contract employee at Northern States Power Company's (Licensee or NSP) Prairie Island Nuclear Generating Plant (PINGP), working under temporary unescorted access authorization. NSP holds Facility Licenses No. DPR-42 and DPR-60, which were issued by the Nuclear. Regulatory Commission (NRC or Commission) pursuant to 10 CFR Part 50 on August 9, 1973, and October 29, 1974, respectively. These licenses authorize the operation of PINGP in accordance with the conditions specified therein. The facility is located on the Licensee's site in Minnesota.

In accordance with 10 CFR 73.56, nuclear power plant licensees must conduct access authorization programs for individuals seeking unescorted access to protected and vital areas of the plant with the objective of providing high assurance that individuals granted. unescorted access are trustworthy and reliable and do not constitute an unreasonable risk to the health and safety of the public. Pursuant to 10 CFR 73.56, the unescorted access authorization 
program must include, at a minimum, verification of an individual's true identity, verification of an individual's character and reputation, and development of information concerning an individual's criminal history; and the decision to grant unescorted access authorization must be based on the licensee's review and evaluation of all pertinent information.

In order to be certified for unescorted access at PINGP, as a contractor employee, Mr. Barnhart completed the security background questionnaire under the assumed name of his deceased brother, Mr. Gregory Kenneth Barnhart, on December 7, 1995. In February 1996, NSP received information concerning Mr. Barnhart's deception before Mr. Barnhart's full background investigation had been completed. A subsequent NSP record review found that Mr. Barnhart's true identity was Jeffrey Lee Barnhart and that he had submitted falsified documents in his request for access authorization. NSP interviewed Mr. Barnhart and determined that he had obtained a driver's license under the assumed name and had been using a false identity for several years. Additionally, Mr. Barnhart admitted that, contrary to his responses on the Security Questionnaire, he had used and was once cited for possession of marijuana. Based on this information, NSP denied Mr. Barnhart's access on February 8, 1996.

An investigative report was prepared by the NSP security department regarding the falsification of the licensee's access authorization documents. The report was reviewed during an investigation conducted by the NRC Office of 
Investigations (OI), which was initiated on February 3, 1997. The OI investigation concluded that Mr. Barnhart had deliberately falsified his application for unescorted access, and was working under the assumed name of his deceased brother.

On April 24, 1997, a Demand for Information (DFI) was issued to Mr. Barnhart pursuant to 10 CFR 2.204 to determine whether enforcement action should be taken against him to ensure future compliance with NRC requirements. The DFI requested that Mr. Barnhart submit information by May 24, 1997, describing why the NRC should have confidence that he would provide complete and accurate information to NRC 1 icensees and the Commission in the future. Mr. Barnhart did not respond to the DFI.

Based on the above, the NRC has concluded that Mr. Barnhart engaged in deliberate misconduct by deliberately assuming the identity of his deceased brother on his personal history questionnaire and misinforming the licensee as to his history of drug use and conviction for possession of marijuana. Mr. Barnhart's actions constitute a violation of 10 CFR 50.5 (a)(2), which prohibits an individual from deliberately providing information to a licensee or contractor that the individual knows is inaccurate or incomplete in some respect material to the NRC. The information that Mr. Barnhart provided regarding his background information was material because, as indicated above, licensees are required to consider such information in making unescorted access determinations in accordance with the requirements of 10 CFR 73.56 . 
The NRC must be able to rely on the Licensee, its contractors, and Licensee and contractor employees to comply with NRC requirements, including the requirement to provide information that is complete and accurate in all material respects. Mr. Barnhart's actions in deliberately providing false information to the Licensee constitute deliberate violations of Commission regulations, and his conduct raises serious doubt about his trustworthiness and reliability and as to whether he can be relied upon to comply with NRC requirements and to provide complete and accurate information to NRC Licensees and their contractors in the future.

Consequently, I lack the requisite reasonable assurance that licensed activities can be conducted in compliance with the Commission's requirements and that the health and safety of the public would be protected if Mr. Barnhart were permitted at this time to be involved in NRC-Ticensed activities. Therefore, the public health, safety and interest require that Mr. Barnhart be prohibited from any involvement in NRC-Ticensed activities for a period of five years from the date of this order. If Mr. Barnhart is currently involved with another licensee in NRC-licensed activities, Mr. Barnhart must immediately cease such activities, and inform the NRC of the name, address and telephone number of the employer, and provide a copy of this Order to the employer. Additionally, Mr. Barnhart is required to notify the NRC of his employment in NRC-licensed activities for a period of five years 
following the prohibition period. Furthermore, pursuant to 10 CFR 2.202, I find that the significance of Mr. Barnhart's conduct described above is such that the public health, safety and interest require that this order be immediately effective.

Accordingly, pursuant to sections 103,161b,161c, $161 \mathrm{i}$ and 186 of the Atomic Energy Act of 1954, as amended, and the Commission's regulations in 10 CFR 2.202 and 10 CFR 50.5, IT IS HEREBY ORDERED, EFFECTIVE IMMEDIATELY, THAT:

1. Mr. Jeffrey Lee Barnhart, a.k.a. Mr. Gregory Kenneth Barnhart, is prohibited from engaging in activities licensed by the NRC for five years from the date of this Order. For the purposes of this order, licensed activities are those activities that are conducted pursuant to a specific or general license issued by the NRC, including, but not limited to, those activities of Agreement State licensees conducted pursuant to the authority granted by 10 CFR 150.20 .

2. For a period of five years after the five-year period of prohibition has expired, Mr. Barnhart shall, within 20 days of his acceptance of each. employment offer involving NRC-licensed activities or his becoming involved in NRC-licensed activities, as defined in Paragraph IV.1 above, provide notice to the Director, Office of Enforcement, U.S. Nuclear Regulatory Commission, Washington, D.C. 20555, of the name, address, and telephone number of the employer or the entity where he is, or will be, 
involved in the NRC-licensed activities. In the first notification, Mr. Barnhart shall include a statement of his commitment to comply with NRC regulatory requirements and the basis for the Commission to have confidence that he will now comply with applicable NRC requirements.

The Director, OE, may, in writing, relax or rescind any of the above conditions upon demonstration by Mr. Barnhart of good cause.

V

In accordance with 10 CFR 2.202, Mr. Barnhart must, and any other person adversely affected by this Order may, submit an answer to this Order, and may request a hearing on this Order within 20 days of the date of this Order. Where good cause is shown, consideration will be given to extending the time to request a hearing. A request for extension of time must be made in writing to the Director, Office of Enforcement, U.S. Nuclear Regulatory Commission, Washington, D.C. 20555, and include a statement of good cause for the extension: The answer may consent to this Order. Unless the answer consents to this Order, the answer shall, in writing and under oath or affirmation, specifically admit or deny each allegation or charge made in this order and shall set forth the matters of fact and law on which Mr. Barnhart or other person adversely affected relies and the reasons as to why the Order should not have been issued. Any answer or request for a hearing shall be submitted 
to the Secretary, U. S. Nuclear Regulatory Commission, ATTN: Chief, Rulemakings and Adjudications, Washington, DC 20555. Copies also shall be sent to the Director, Office of Enforcement, U. S. Nuclear Regulatory Commission, Washington, DC 20555, to the Assistant General Counsel for Hearings and Enforcement at the same address, to the Regional Administrator, Region III, U. S. Nuclear Regulatory Commission, 801 Warrenville Road, Lisle, Illinois 60532-4351, and to Mr. Barnhart, if the answer or hearing request is by a person other than Mr. Barnhart. If a person other than Mr. Barnhart requests a hearing, that person shall set forth with particularity the manner in which his or her interest is adversely affected by this Order and shall address the criteria set forth in 10 CFR $2.714(d)$.

If a hearing is requested by Mr. Barnhart or a person whose interest is adversely affected, the Commission will issue an order designating the time and place of any hearing. If a hearing is held, the issue to be considered at such hearing shall be whether this Order should be sustained.

Pursuant to 10 CFR 2.202 (c)(2)(i), Mr. Barnhart may, in addition to demanding a hearing, at the time that answer is filed or sooner, move the presiding officer to set aside the immediate effectiveness of the Order on the ground that the Order, including the need for immediate effectiveness, is not based on adequate evidence but on mere suspicion, unfounded allegations, or error.

In the absence of any request for hearing, or written approval of an extension of time to request a hearing, the provisions specified in Section IV above shall be final 20 days from the date of this order without further order or 
proceedings. If an extension of time for requesting a hearing has been approved, the provisions specified in Section IV shall be final when the extension expires if a hearing request has not been received. AN ANSWER OR A REQUEST FOR A HEARING SHALL NOT STAY THE IMMEDIATE EFFECTIVENESS OF THIS ORDER.

FOR THE NUCLEAR REGULATORY COMMISSION

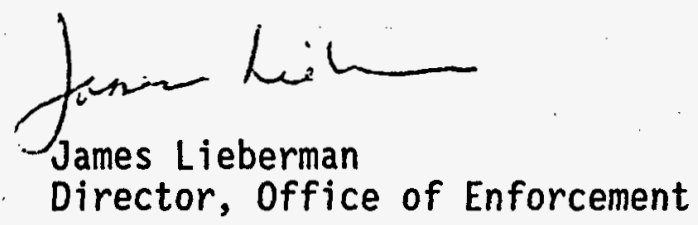

Dated at Rockville, Maryland this.j3" day of June 1997 


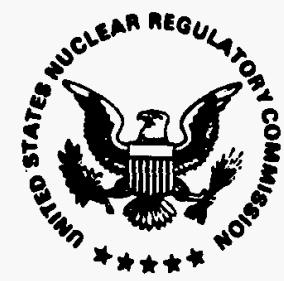

UNITED STATES

NUCLEAR REGULATORY COMMISSION

WASHINGTON, D.C. 20065-0001

May 27, 1997

IA $97-032$

Mr. Daniel R. Baudino

HOME ADDRESS DELETED

UNDER 2.790

Dear Mr. Baudino:

SUBJECT: ORDER PROHIBITING INVOLVEMENT IN NRC-LICENSED ACTIVITIES

(EFFECTIVE IMMEDIATELY) (OI REPORT NO. 3-96-008)

The enclosed Order Prohibiting Involvement in NRC-Licensed Activities is being issued as a consequence of your deliberately providing false information on applications you made for access authorization at the Commonwealth Edison Company's (1icensee) Oresden Nuclear Station. The Order prohibits your involvement in NRC-ficensed activities for a period of five years.

Specifically, you falsely indicated on forms entitled "Personal History Questionnaire for Unescorted Access" dated August 21, 1990, August 5, 1991, January 16, 1992, and October 5, 1992, that you had not been arrested and/or convicted of any criminal offense when, in fact, you had been arrested and convicted of multiple misdemeanors as of these dates.

The false information that you submitted on your personal history questionnaires dated January 16, 1992, and October 5, 1992, caused you to be in violation of 10 CFR 50.5 (Deliberate Misconduct). Specifically, 10 CFR $50.5(a)(2)$ provides, in part, that any employee of a contractor may not deliberately submit to a licensee or a licensee's contractor information that the person submitting the information knows to be incomplete or inaccurate in some respect material to the NRC. The false information that you submitted was material because licensees are required to consider criminal history in making a determination as to whether to grant you unescorted access in accordance with 10 CFR 73.56.

While you deliberately made the same false statements on your personal history questionnaires of August 21, 1990 and August 5, 1991, those instances are not being cited in the enclosed Order because they occurred prior to September 16, 1991, the date that 10 CFR 50.5 became effective.

Pursuant to Section 223 of the Atomic Energy Act of 1954, as amended, 42 U.S.C. 2273, any person who willfully violates, attempts to violate, or conspires to violate any provision of this Order shall be subject to criminal prosecution as set forth in that section. Violation of this order may also subject the person to civil monetary penalty.

Questions concerning the Order may be addressed to James Lieberman, Director, Office of Enforcement. Mr. Lieberman can be reached at telephone number (301) 415-2741.

NUREG-0940, PART I A-52 
In accordance with 10 CFR 2.790 of the NRC's "Rules of Practice", a copy of this letter and the enclosure with your home address removed will be placed in the NRC's Public Document Room.

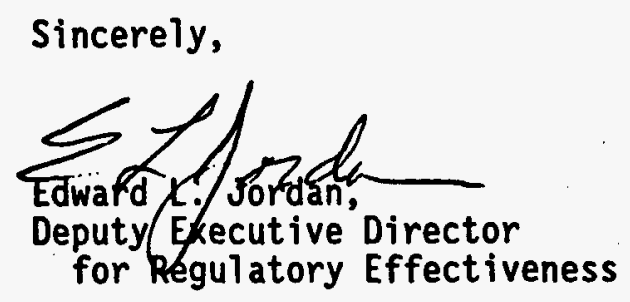

Enclosure: Order Prohibiting Involvement in

NRC-Licensed Activities (Effective Immediately) 


\section{UNITED STATES \\ NUCLEAR REGULATORY COMMISSION}

In the Matter of

MR. DANIEL R. BAUDINO

$$
\text { \} }
$$

IA $97-032$

ORDER PROHIBITING INVOLVEMENT IN

NRC-LICENSED ACTIVITIES

(EFFECTIVE IMMEDIATELY)

\section{I}

Mr. Daniel R. Baudino was formerly employed by Bechtel Constructors Inc. (Bechtel) at the Commonwealth Edison Company's Dresden Nuclear Station (ComEd, Dresden, or Licensee) where he was granted unescorted access. ComEd holds Facility Licenses No. DPR-2, No. DPR-19, and No. DPR-25 issued by the Nuclear Regulatory Commission (NRC or Commission) pursuant to 10 CFR Part 50. These licenses authorize ComEd to operate the Dresden Nuclear Station, Units 2 and 3, and possess and maintain but not operate Unit 1 (Dresden Station) located near Morris, Illinois, in accordance with the conditions specified therein.

In accordance with 10 CFR 73.56, nuclear power plant licensees must conduct access authorization programs for individuals seeking unescorted access to protected and vital areas of the plant with the objective of providing high assurance that individuals granted unescorted access are trustworthy and reliable and do not constitute an unreasonable risk to the health and safety of the public. The unescorted access authorization program must include a background investigation, including criminal history. The decision to grant unescorted access authorization must be based on the licensee's review and evaluation of all pertinent information.

In order to be certified for unescorted access at Dresden Station as a contractor employee, Mr. Baudino completed Dresden Station forms entitled 
"Personal History Questionnaires for Unescorted Access" (personal history questionnaires) on several occasions, including January 16, 1992, and October 5, 1992. On each of these forms, Mr. Baudino indicated and certified with his signature that he had never been arrested and convicted of a criminal proceeding for the violation of any law, regulation or ordinance, including driving under the influence or traffic offenses other than non-personal injury traffic or parking offenses. Mr. Baudino was subsequently granted unescorted access to the Dresden station on each occasion, based in part on his representations on the personal history questionnaires that he had no criminal history. Mr. Baudino's unescorted access to the Dresden Station was revoked for cause by the Licensee on December 5, 1995, for other reasons than accurately completing his personal history questionnaire.

During an investigation by the NRC Office of Investigations (OI) at the Dresden Station, Mr. Baudino was interviewed by OI on March 14, 1996. During the interview, Mr. Baudino was shown copies of the personal history questionnaires referenced above and acknowledged that the signatures on each of the forms were his.

Mr. Baudino also acknowledged that his marking of an " $x$ " in the "no" block under the question regarding criminal history indicated that he had not been arrested or convicted of any offenses. When confronted with the arrest records that OI had obtained from the Grundy County, Illinois, Circuit Court, which revealed that $\mathrm{Mr}$. Baudino had multiple arrests and convictions during the period of 1987 to October 5, 1992, Mr. Baudino admitted they were records of his arrests. Mr. Baudino stated that he thought the questions pertained to federal arrests and convictions when asked why he falsely reported on the forms that he had no criminal history. 
In a report issued on September 23, 1996, OI concluded that Mr. Baudino deliberately falsified his criminal history information on the personal history questionnaires in order to gain unescorted access to the Dresden Station.

Based on the above, the NRC has concluded that Mr. Baudino engaged in deliberate misconduct on January 16, 1992, and October 5, 1992, by deliberately falsely stating on the personal history questionnaires he signed on those dates that he had no criminal history. Mr. Baudino's actions constitute a violation of 10 CFR $50.5(a)(2)$, which prohibits an individual from deliberately providing information to a licensee or contractor that the individual knows is inaccurate or incomplete in some respect material to the NRC. The information that Mr. Baudino provided regarding his criminal history was material because, as indicated above, licensees are required to consider such information in making unescorted access determinations in accordance with the requirements of 10 CFR 73.56 .

The NRC must be able to rely on the Licensee, its contractors, and the Licensee and contractor employees to comply with NRC requirements, including the requirement to provide information that is complete and accurate in all material respects. Mr. Baudino's actions in deliberately providing false information to the Licensee constitute deliberate violations of Commission regulations, and his doing so on multiple occasions raises serious doubt as to whether he can be relied upon to comply with NRC requirements and to provide complete and accurate information to NRC Licensees and their contractors in the future, and raises doubt about his trustworthiness and reliability. 
Consequently, I lack the requisite reasonable assurance that licensed activities can be conducted in compliance with the Commission's requirements and that the health and safety of the public would be protected if Mr. Baudino were permitted at this time to be involved in NRC-licensed activities. Therefore, the public health, safety and interest require that Mr. Baudino be prohibited from any involvement in NRC-licensed activities for a period of five years from the date of this Order, and if Mr. Baudino is currently involved with another licensee in NRC-licensed activities, Mr. Baudino must immediately cease such activities, and inform the NRC of the name, address and telephone number of the employer, and provide a copy of this Order to the employer. Additionally, Mr. Baudino is required to notify the NRC of his first employment in NRC-licensed activities following the prohibition period. Furthermore, pursuant to 10 CFR 2.202, I find that the significance of Mr. Baudino's conduct described above is such that the public health, safety and interest require that this Order be immediately effective.

\section{IV}

Accordingly, pursuant to sections 103,161b,16lc, 161i and 186 of the Atomic Energy Act of 1954, as amended, and the Commission's regulations in 10 CFR 2.202, 10 CFR 50.5 and 10 CFR 150.20, IT IS HEREBY ORDERED, EFFECTIVE IMMEDIATELY, THAT :

1. Mr. Daniel $R$. Baudino is prohibited from engaging in activities licensed by the NRC for five years from the date of this order. NRC-licensed activities are those activities that are conducted pursuant to a specific or general license issued by the NRC, 
including, but not limited to, those activities of Agreement State licensees conducted pursuant to the authority granted by 10 CFR 150.20 .

2. For a period of five years after the five year period of prohibition has expired, Mr. Baudino shall, within 20 days of his acceptance of each employment offer involving NRC-licensed activities or his becoming involved in NRC-licensed activities, as defined in Paragraph IV.1 above, provide notice to the Director, Office of Enforcement, U.S. Nuclear Regulatory Commission, Washington, D.C. 20555, of the name, address, and telephone number of the employer or the entity where he is, or will be, involved in the NRC-licensed activities. In the first notification, Mr. Baudino shall include a statement of his commitment to compliance with regulatory requirements and the basis why the Commission shall have confidence that he will now comply with applicable NRC requirements.

The Director, $O E$, may, in writing, relax or rescind any of the above conditions upon demonstration by Mr. Baudino of good cause.

In accordance with 10 CFR 2.202, Mr. Baudino must, and any other person adversely affected by this Order may, submit an answer to this Order, and may request a hearing on this Order within 20 days of the date of this Order. Where good cause is shown, consideration will be given to extending the time 
to request a hearing. A request for extension of time must be made in writing to the Director, Office of Enforcement, U.S. Nuclear Regulatory Commission, Washington, D.C. 20555, and include a statement of good cause for the extension. The answer may consent to this Order. Unless the answer consents to this Order, the answer shall, in writing and under oath or affirmation, specifically admit or deny each allegation or charge made in this Order and shall set forth the matters of fact and law on which Mr. Baudino or other person adversely affected relies and the reasons as to why the Order should not have been issued. Any answer or request for a hearing shall be submitted to the Secretary, U. S. Nuclear Regulatory Commission, ATTN: Chief, Rulemakings and Adjudications, Washington, DC 20555. Copies also shall be sent to the Director, Office of Enforcement, U. S. Nuclear Regulatory Commission, Washington, DC 20555, to the Assistant General Counsel for Hearings and Enforcement at the same address, to the Regional Administrator, Region III, U. S. Nuclear Regulatory Commission, 801 Warrenville Road, Lisle, Illinois 60532-4351, and to Mr. Baudino, if the answer or hearing request is by a person other than Mr. Baudino.. If a person other than Mr. Baudino requests a hearing, that person shall set forth with particularity the manner in which his interest is adversely affected by this Order and shall address the criteria set forth in 10 CFR $2.714(d)$.

If a hearing is requested by Mr. Baudino or a person whose interest is adversely affected, the Commission will issue an Order designating the time and place of any hearing. If a hearing is held, the issue to be considered at such hearing shall be whether this Order should be sustained. 
Pursuant to 10 CFR 2.202(c)(2)(i), Mr. Baudino may, in addition to demanding a hearing, at the time that answer is filed or sooner, move the presiding officer to set aside the immediate effectiveness of the Order on the ground that the Order, including the need for immediate effectiveness, is not based on adequate evidence but on mere suspicion, unfounded allegations, or error.

In the absence of any request for hearing, or written approval of an extension of time to request a hearing, the provisions specified in Section IV above shall be final 20 days from the date of this Order without further order or proceedings. If an extension of time for requesting a hearing has been approved, the provisions specified in Section IV shall be final when the extension expires if a hearing request has not been received. AN ANSWER OR A REQUEST FOR A HEARING SHALL NOT STAY THE IMMEDIATE EFFECTIVENESS OF THIS ORDER.

FOR THE NUCLEAR REGULATORY COMMISSION

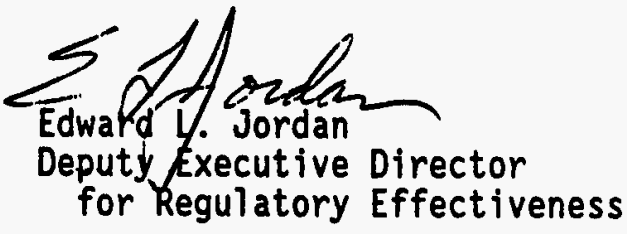

Dated at Rockville, Maryland this 27thday of May 1997 


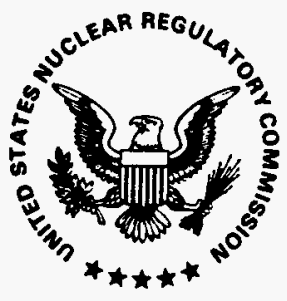

\section{UNITED STATES \\ NUCLEAR REGULATORY COMMISSION \\ WASHINGTON, D.C. 20555-0001}

August 5, 1997

IA 97-059

Ms. Sue A. Blacklock

HONE ADDRESS DELETED

INDER 2.790

Dear Ms. Blacklock:

SUBJECT: $\quad$ ORDER PROHIBITING INVOLVEMENT IN NRC-LICENSED AC.TIVITIES

(EFFECTIVE IMMEDIATELY)

(NRC Office of Investigations Report NO. 1-96-006)

The enclosed Order Prohibiting Involvement in NRC-Licensed Activities is being issued to you as a consequence of the findings by the NRC Office of Investigations (OI) that you deliberately directed falsification of Reactor Enclosure Cooling Water (RECW) sample documentation on February 7, 1996. The synopsis of the OI investigation was forwarded to you on May 21, 1997. The NRC has concluded that you violated 10 CFR 50.5(a)(1) which provides, in part, that an employee of a licensee may not engage in deliberate misconduct that causes a licensee to be in violation of any rule, regulation, order, or condition of the license. Specifically, your deliberate actions of directing the falsification of a record of a chemistry sample caused PECO Energy Company to violate 10 CFR 50.9. A predecisional enforcement conference was held with you on June 3,1997 to discuss this apparent violation, its causes, and your corrective action.

The Order prohibits your involvement in NRC-1icensed activities for a period of 5 years. In addition, subsequent to the 5-year period, the Order requires that you notify the NRC the first time you accept employment involving NRClicensed activities or your becoming involved in NRC-licensed activities. Pursuant to Section 223 of the Atomic Energy Act of 1954, as amended, 42 U.S.i. 2273, any person who willfully violates, attempts to violate, or conspires to violate any provision of this order shall be subject to criminal prosecuition as set forth in that section. Violation of this order may also subject the person to civil monetary penalty.

Questions cuncerning this Order may be addressed to James Lieberman, Director, Office of Enforcement. Mr. Lieberman can be reached at telephone number (301) 415-2741. Also attached is a Proposed Notice of Violation and Proposed Imposition of Civil Penalty issued on this date to PECO Energy Company for the falsification of records that was based, in part, on your deliberate actions. 
In accordance with 10 CFR 2.790 of the NRC's "Rules of Practice", a copy of this letter and the enclosure with your home address removed will be placed in the NRC's Public Document Room.

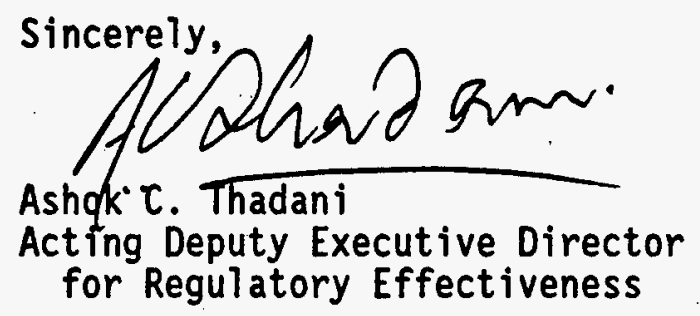

Enclosures:

1. Order Prohibiting Involvement in NRC-Licensed Activities (Effective Immediately)

2. Notice of Violation and Proposed Imposition of Civil Penalty to PECO Energy Company

Cc w/encl:

D. M. Smith, President, PECO Nuclear Commonwealth of Pennsyivania 


\section{UNITED STATES \\ NUCLEAR REGULATORY COMMISSION}

In the Matter of

MS. SUSAN A. BLACKLOCK

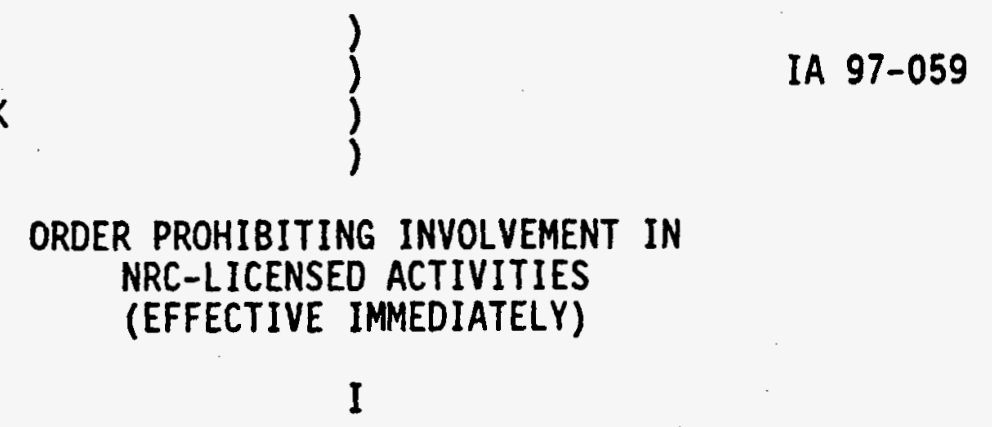

Ms. Sue A. Blacklock (Ms. Blacklock) was formerly employed by PECO Energy Company at the Limerick Generating Station (PECO, Limerick, or Licensee) as the Primary Chemistry Manager. PECO holds Facility License Nos. NPF-39 and NPF-84 issued by the Nuclear Regulatory Commission (NRC or Commission) pursuant to 10 CFR Part 50. These licenses authorize PECO to operate the Limerick Station, Units 1 and 2, in accordance with the conditions specified therein.

On February 7, 1996, while a Reactor Enclosure Cooling Water (RECW) radiation monitor was inoperable, the Licensee was required, in accordance with Technical Specification 3.3.7.1, ACTION 72, to obtain and analyze at least one grab sample from the RECW system at least once per 24 hours. On that date, the sample needed to be taken by 11:00 a.m. to meet that requirement. The sample was not taken until 12:15 p.m. on that date, approximately 1 hour and 15 minutes after the time it was due. However, the record of the grab sample RECW Surveillance Test (ST-5-026-570-1, "Inop Reactor Enclosure Cooling Water Rad Mon Grab Sampling and Analysis"), signed by a chemistry technician and the chemist (as chemistry supervision), was inaccurate because (1) page one of 
attachment 1 of the test record indicated that the time of the sample was 11:00 a.m., and (2) the attached computer printout of the Gamma Spectrum Analysis (required by step 4.3 .1 of the surveillance test) also indicated that the sample was taken at 11:00 a.m.. The creation of this inaccurate record caused the Licensee to be in violation of 10 CFR 50.9, "Completeness and accuracy of information."

Afterwards, an investigation of this matter was conducted by. PECO, and the NRC was informed of the findings. Subsequentiy, an investigation was conducted by the NRC Office of Investigations (OI), that determined, based upon the evidence developed during its investigation, and a review of evidence contained in the investigation report provided by PECO, that on February 7 , 1996, the former PECO chemist and the PECO chemistry technician deliberately falsified RECW sample documentation, at the direction of Ms. Blacklock, the former PECO Primary Chemistry Manager.

Ms. Blacklock denied, both in her November 7, 1996, interview with 01 , as well as during a June 3, 1997 predecisional enforcement conference with the NRC, that she had instructed the chemistry technician to rewrite the surveillance test, and also denied that she had instructed the chemist to change the sample time in the computer. Notwithstanding that denial, both the chemistry technician and the chemist stated in their interviews with $0 \mathrm{I}$, that it was Ms. Blacklock's idea to rewrite the surveillance test document and that she subsequently ordered that the sample time in the computer be changed. In addition, the original data sheet corroborates that the chemistry technician originaliy entered the proper sample time as 12:15 p.m.. Therefore, contrary 
to the Ms. Blacklock's denials, the NRC has concluded that Ms. Blacklock instructed the former PECO chemist and chemistry technician to falsify the RECW sample documentation.

\section{III}

Based on the above, the NRC has concluded that Ms. Blacklock engaged in deliberate misconduct by directing falsification of the time of the RECW grab sample. Ms. Blacklock's actions constitute a violation of 10 CFR $50.5(a)(1)$, which prohibits an individual from engaging in deliberate misconduct that causes or, but for detection, would have caused, a licensee to be in violation of any rule, regulation, or order, or any term, condition, or limitation of any license, issued by the Commission. In this case, Ms. Blacklock caused the Licensee to be in violation of 10 CFR 50.9, "Completeness and accuracy of information."

The NRC must be able to rely on the Licensee, its contractors, and the Licensee and contractor employees to comply with NRC requirements, including the requirement to maintain information that is complete and accurate in all material respects. Ms. Blacklock's action in directing falsification of records, and her collusion with others to hide that falsification, constitutes a deliberate violation of Commission regulations, and her doing so raises serious doubt as to whether she can be relied upon to comply with NRC requirements and to maintain complete and accurate information for NRC Licensees and Licensee contractors in the future, and raises doubt about her trustworthiness and reliability. 
Consequently, I lack the requisite reasonable assurance that licensed activities can be conducted in compliance with the Commission's requirements and that the health and safety of the public would be protected if Ms. Blacklock were permitted at this time to be involved in NRC-licensed activities. Therefore, the public health, safety and interest require that Ms. Blacklock be prohibited from any involvement in NRC-licensed activities for a period of 5 years from the date of this Order, and if Ms. Blacklock is currently involved with another licensee in NRC-licensed activities, Ms. Blacklock must immediateTy cease such activities, and inform the NRC of the name, address and telephone number of the employer, and provide a copy of this Order to the employer. Additionally, Ms. Blacklock is required to notify the NRC of her first employment in NRC-licensed activities following the prohibition period. Furthermore, pursuant to 10 CFR 2.202, I find that the significance of Ms. Bracklock's conduct described above is such that the public health, safety and interest require that this order be immediately effective.

\section{IV}

Accordingly, pursuant to sections 103,161b,161i,1610,182 and 186 of the Atomic Energy Act of 1954, as amended, and the Commission's regulations in 10 CFR 2.202, 10 CFR 50.5, and 10 CFR 150.20, IT IS HEREBY ORDERED, EFFECTIVE IMMEDIATELY, THAT:

1. Sue A. Blacklock is prohibited from engaging in activities licensed by the NRC for 5 years from the date of this Order. NRC-licensed 
activities are those activities that are conducted pursuant to a specific or general 1 icense issued by the NRC, including, but not limited to, those activities of Agreement State licensees conducted pursuant to the authority granted by 10 CFR 150.20 .

2. After the 5-year period of prohibition has expired, Ms. Blacklock shall, within 20 days of her acceptance of the first employment offer involving NRC-licensed activities or her becoming involved in NRC-licensed activities, as defined in Paragraph IV.I above, provide notice to the Director, Office of Enforcement, U. S. Nuclear Regulatory Commission, Washington, D.C. 20555, of the name, address, and telephone number of the employer or the entity where she is, or will be, involved in the NRC-licensed activities. In the notification, Ms. Blacklock shall include a statement of her commitment to compliance with regulatory requirements and the basis why the Commission should have confidence that she will now comply with applicable NRC requirements.

The Director, OE, may, in writing, relax or rescind any of the above conditions upon demonstration by Ms. Blacklock of good cause.

\section{V}

In accordance with 10 CFR 2.202, Ms. Blacklock must, and any other person adversely affected by this Order may, submit an answer to this Order, and may request a hearing on this Order, within 20 days of the date of this Order. Where good cause is shown, consideration will be given to extending the time 
to request a hearing. A request for extension of time must be made in writing to the Director, Office of Enforcement, U.S. Nuclear Regulatory Commission Washington, D.C. 20555, and include a statement of good cause for the extension. The answer may consent to this Order. Unless the answer consents to this Order, the answer shall, in writing and under oath or affirmation, specifically admit or deny each allegation or charge made in this order and shall set forth the matters of fact and law on which Ms. Blacklock or other person adversely affected relies and the reasons as to why the Order should not have been issued. Any answer or request for a hearing shall be submitted to the Secretary, U.S. Nuclear Regulatory Commission, Attn: Chief, Rulemakings and Adjudications Staff, Washington, DC 20555. Copies also shall be sent to the Director, Office of Enforcement, U.S. Nuclear Regulatory Commission, Washington, $D C 20555$, to the Assistant General Counsel for Hearings and Enforcement at the same address, to the Regional Administrator, NRC Region I, U.S. Nuclear Regulatory, 475 Allendale Road, King of Prussia, Pennsylvania 19406, and to Ms. Blacklock if the answer or hearing request is by a person other than Ms. Blacklock. If a person other than Ms. Blacklock requests a hearing, that person shall set forth with particularity the manner in which that person's interest is adversely affected by this order and shall address the criteria set forth in 10 CFR 2.714(d).

If a hearing is requested by Ms. Blacklock or a person whose interest is adversely affected, the Commission will issue an Order designating the time and place of any hearing. If a hearing is held, the issue to be considered at such hearing shall be whether this order should be sustained. 
Pursuant to 10 CFR $2.202(c)(2)(i)$, Ms. Blacklock may, in addition to demanding a hearing, at the time the answer is filed or sooner, move the presiding officer to set aside the immediate effectiveness of the Order on the ground that the Order, including the need for immediate effectiveness, is not based on adequate evidence but on mere suspicion, unfounded allegations, or error.

In the absence of any request for hearing, or written approval of an extension of time in which to request a hearing, the provisions specified in Section IV above shall be final 20 days from the date of this Order without further order or proceedings. If an extension of time for requesting a hearing has been approved, the provisions specified in Section IV shall be final when the extension expires if a hearing request has not been received. AN ANSWER OR A REQUEST FOR HEARING SHALL NOT STAY THE IMMEDIATE EFFECTIVENESS OF THIS ORDER.

FOR THE NUCLEAR REGULATORY COMMISSION

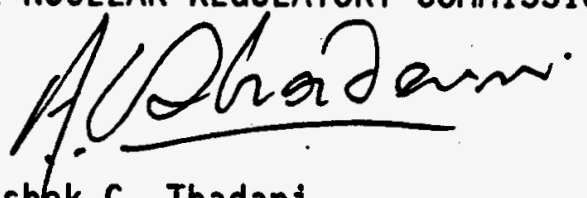

Ashpk C. Thadani

Acting Deputy Executive Director for Regulatory Effectiveness

Dated at Rockville, Maryland this 5 ש day of August 1997 


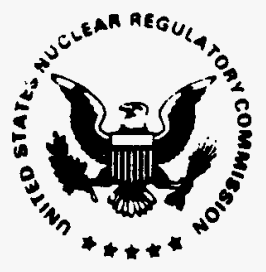

\section{UNITED STATES \\ NUCLEAR REGULATORY COMMISSION \\ WASHINGTON, D.C. 20086-0001}

\section{SEP $\because 8$ iSS4.}

Docket No. 030-02551

License No. 29-12417-01

iA 94-023

Jerome E. Bodian, M.D.

[HOME ADDRESS DELETED

UNDER 2.790]

Dear Dr. Bodian:

\section{SUBJECT: CONFIRMATORY ORDER (EFFECTIVE IMMEDIATELY)}

On June 24, 1993, the NRC sent you a Demand for Information (DFI) based on several apparent violations of NRC requirements including (1) administration of doses to patients without first checking the dose in a dose calibrator, and (2) making false statements to the NRC during an NRC inspection at your facility on April 6, 1992, and subsequent telephone conversation on ApriT 7, 1992 with NRC staff. The DFI required, in part, that you provide the reasons why, in light of the apparent violations described therein, the NRC should not issue an Order that precludes you from any involvement in NRC licensed activities in the future.

In your sworn response dated July 20, 1993, to the DFI, you: (1) stated that on infrequent occasions, a precalibrated dose of radioiodine was administered without prior use of a dose calibrator; (2) reiterated a previous request that your license be terminated; and (3) pointed out that you have never used the Englewood Hospital's 11cense on a personal basis and any administration of radiopharmaceuticals to your patients at the Englewood Hospital was done under the supervision of the hospital radiology department.

Based on a NRC Office of Investigation report issued on July 26, 1993, the NRC Staff has determined that you deliberately failed to measure doses before administration to patients, and deliberately provided inaccurate information to the NRC during the Aprif 6, 1992 inspection and the April 7, 1992 telephone conversation. A copy of the synopsis of the investigation is enclosed.

Although the NRC issued amendment No. 07 on September 27, 1993, terminating your license, in telephone conversations between Dr. Ronald R. Bellamy of the NRC Region I office and yourself on July 18,19, and 20, 1994, you agreed to the issuance of an Order that would confirm that you would not participate in activities licensed by the NRC at any facility for a period of five years, and would notify the NRC the first time (if any) you engage in licensed activities after the five year prohibition expires. The enclosed Confirmatory Order (Effective Immediately) confirms these commitments.

Question concerning the Order may be addressed to Ms. Patricia Santiago, Assistant Oirector for Materials, Office of Enforcement, at telephone number (301) 504-3055. 
In accordance with 10 CFR 2.790 of the NRC's "Rules of Practice," a copy of this letter, its enclosures, and your response will be placed in the NRC's Public Document Room.

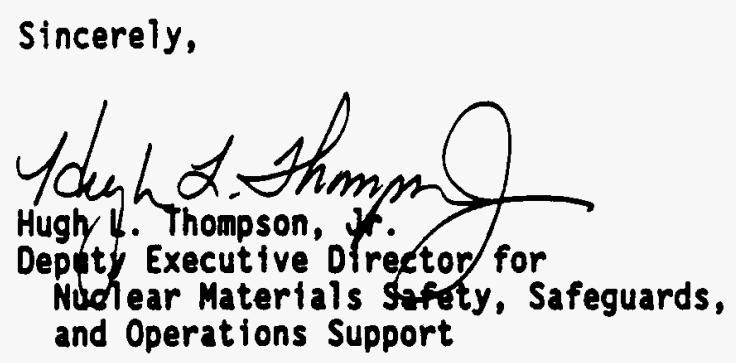

Enclosures:

1. Confirmatory Order (Effective Imnediately)

2. OI Report Synopsis

cc w/encls:

Public Document Roon (POR)

Nuclear Safety Information Center (NSIC)

State of New Jersey

Englewood Hospital 
On May 22, 1992, the Office of Investigations (OI), U.S. Nuclear Regulatory Commission (NRC), Field Office Region 1, initiated an investigation to determine if the licensee intentionally violated NRC regulations by providing inaccurate and/or false information to NRC staff during an April 6, 1992, inspection, and April 7, 1992, telephone conversation. Specifically, the information concerned the licensee having doses of iodine-131 (I-13i) assayed by a technologist at Englewood Hospital (EH) prior to the admintstration of the I-13I to patients.

Based on the evidence, 01 concludes that the licensee deliberately falled to measure the activity of each radtopharmaceutical dose before medical use. In addition, the 1 icensee deliberately provided inaccurate and/or false

information to NRC staff during the April 6, 1992, inspection and April 7, 1992, telephone conversation.

OI also concludes that the licensee deliberately falled to conduct annual survey meter calibrations.

There is insufficient evidence to conclude that the ilcensee deliberately failed to possess a dose caltibrator for the measurement of pattent doses. There is also insufficient evidence to conclude that the licensee deliberately failed to possess appropriate radiation detection and radiation measurement survey instrumentation.

Case No. 1-92-020R 
UNITED STATES

NUCLEAR REGULATORY COMMISSION

In the Matter of

JERONE E. BODINN M.D.

Englewood, New Jersey

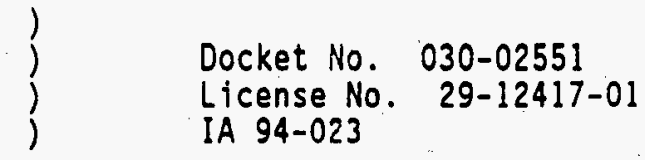

CONFIRMATORY ORDER (EFFECTIVE IMMEDIATELY)

Jerome E. Bodian (Licensee or Jr. Bodian) was the holder of NRC License No. 29-12417-01 (License) issued by the Nuclear Regulatory Commission (NRC or Commission) pursuant to 10 CFR Parts 30 and 35 on September 11, 1967 and last renewed in its entirety on August 20, 1990. The License authorized the Licensee to possess and use iodine-131 as iodide for uptake studies, thyroid imaging, and the treatment of hypothyroidism and cardiac disfunction. The License was due to expire on August 30, 1995; however on January 25, 1993, the Licensee requested that the License be terminated. The NRC granted this request for termination, and Amendment No. 07 was issued to the Licensee on September 27, 1993, terminating the License.

On April 6, 1992, an NRC inspection was conducted at the Licensee's facility in Englewood, New Jersey. During the inspection, the NRC identified several violations of NRC requirements, including the failure to possess and use a dose calibrator to assay therapeutic doses of iodine-131 prior to administration to patients. Also during the inspection, Dr. Bodian told the inspector that he took doses of lodine-131 to Englewood Hospital for calibration. During a telephone conversation with Region I staff on April 7, 1992, Dr. Bodian stated that. (1) although he did not possess a dose 
calibrator, he had a technologist at Englewood Hospital perform the dose measurements for almost all patients he had treated; (2) all measurements of doses were within \pm 10 percent of the prescribed dose; and (3) the resuits of these measurements were recorded in the patient charts.

Shortly after the inspection, the NRC issued a Confirmatory Action Letter to the Licensee on April 9, 1992, which confirmed, in part, the Licensee's agreement to terminate patient treatments with any radiopharmaceutical authorized by the NRC until such time as the Licensee established, and submitted to the NRC for approval, a program that included all of the required equipment and procedures required by 10 CFR Part 35 . Such a program was not established and patient treatment has not resumed. The MRC Office of Investigations initiated an investigation on May 22, 1992. Dr. Bodian requested, in a letter dated January 25, 1993, that the License be terminated.

In view of Dr. Bodian's willful fallure to adhere to NRC requirements, as well as the apparently willful fallure to provide complete and accurate information to the NRC, thereby endangering patients to whom the doses were administered, the NRC needed certain information to determine whether there existed reasonable assurance that Dr. Bodian's activities conducted under other NRC licenses would be perforned safely and in accordance with requirements. Accordingly, a Daand for Information (DFI) was issued to Or. Bodtan on June 24, 1993, that requested $\mathrm{htm}$ to $\mathrm{list}$ all NRC 1 icenses on which he was then listed as an authorized user, and to explain why the NRC should not issue an order to preclude him from any involvement in licansed activities in the future. 
On July 20, 1993, Or. Bodian responded to the Demand for Information stating that (1) on infrequent occasions a precalibrated dose of radioiodine was administered without prior use of dose calibrator; (2) a request for termination of his license (No. 29-12417-01) was made on January 25, 1993; and (3) his listing (as an authorized user) on the Englewood Hospital license (No. 29-08519-01) was a carry over from years ago, and that any administration of radiopharmaceuticals to his patients at Englewood Hospital was done under the supervision of the hospital radiology department.

The NRC OI report issued July 26, 1993 determined that notwithstanding Or. Bodian's statements to the MRC, the doses, with a few exceptions, were not assayed with a dose calfbrator prior to administration, even though Or. Bodian was aware that such assays were required. This finding is based on the fact that although the Licensee's records indicate that 30 lodine-131 doses were provided to patients between January 1990 and April 1992, the NRC has found that most doses were not assayed for the Licensee in the Hospital's dose calibrator during that time. This willful fallure to adhere to this requirement, as well as the willful false statements to the NRC during the inspection on April 6. 1992 and the April 7, 1992 telephone conversation, constitute violations of 10 CFR 35.53, 10 CFR 30.9, and 10 CFR 30.10 .

Based on the above, it appears that Dr. Bodtan, the Licensee, engaged in deliberate misconduct that constitutes a violation of 10 CFR $30.10(2)(1)$ and that has caused the Licensee to be in violation of 10 CFR 35.53. It further 
appears that Or. Bodian deliberately provided to NRC inspectors information that he knew to be incomplete or inaccurate in some respect materfal to the NRC, in violation of 10 CFR 30.09 and 10 CFR $30.10(a)(2)$. Or. Bodian has demonstrated an unwillingness to comply with Comission requirements. NRC must be able to rely on its licensees to comply with NRC requirements, including the requirament to provide complete and accurate information. Willful violations are of particular concern to the Comatssion because they undermine the Commission's reasonable assurance that 1icensed activities will be conducted in accordance with NRC requirements. Or. Bodian's actions have raised serious doubt as to whether he can be relied upon to comply with NRC requirements and to provide complete and accurate information to the MRC.Consequently, protection of the public health, safety and interest require that Dr. Bodian be prohibited from engaging in NRC-licensed activities for a period of 5 years and to notify the NRC prior to resumption of any NRClicensed activities at any facllity after termination of the five year prohibition.

In telephone conversations on July 18, 19, and 20, 1994, with Dr. Ronald R. Bellany of the MRC Region I office, Dr. Bodian agreed not to be involved in any NRC-1icansed activities for a period of five years, and to notify the NRC prior to resuption of any licensed activities at any facility after that five year prohibition. I find that the Or. Bodian's comitants as set forth in that conversation are acceptable and necessary and conclude that with these comitments the protection of the public health and safety is reasonably assured. In view of the foregoing, I have deterwined that the public health and safety require that the Dr. Bodian's commitments in the telephone 